\title{
Effect of seasonal variation on the composition and properties of raw milk destined for processing in the UK
}

Article

Accepted Version

Chen, B., Lewis, M. and Grandison, A. (2014) Effect of seasonal variation on the composition and properties of raw milk destined for processing in the UK. Food Chemistry, 158. pp. 216-223. ISSN 0308-8146 doi:

https://doi.org/10.1016/j.foodchem.2014.02.118 Available at https://centaur.reading.ac.uk/36075/

It is advisable to refer to the publisher's version if you intend to cite from the work. See Guidance on citing.

To link to this article DOI: http://dx.doi.org/10.1016/j.foodchem.2014.02.118

Publisher: Elsevier

All outputs in CentAUR are protected by Intellectual Property Rights law, including copyright law. Copyright and IPR is retained by the creators or other copyright holders. Terms and conditions for use of this material are defined in the End User Agreement.

www.reading.ac.uk/centaur 
Central Archive at the University of Reading

Reading's research outputs online 
1 Effect of Seasonal variation on the composition and properties of raw milk

2 destined for processing in the UK

3 Biye Chen, Michael J. Lewis and Alistair S. Grandison*

4 Department of Food and Nutritional Sciences, University of Reading, Whiteknights, PO Box

5 226, Reading RG6 6AP, UK

$6 \quad *$ Corresponding author - Tel. +44 (0) 118378 6724; Fax. +44 (0) 3787708

7 Abstract (150 words max)

8 The composition and physical properties of raw milk from a commercial herd were studied

9 over a one year period in order to understand how best to utilise milk for processing throughout the year. Protein and fat levels demonstrated seasonal trends, while minerals and many physical properties displayed considerable variations, which were apparently unrelated to season. However, rennet clotting time, ethanol stability and foaming ability were subject to seasonal variation. Many significant interrelationships in physico-chemical properties were found. It is clear that the milk supply may be more suited to the manufacture of different products at different times of the year or even on a day to day basis. Subsequent studies will report on variation in production and quality of products manufactured from the same milk samples described in the current study and will thus highlight potential advantages of seasonal processing of raw milk.

Highlights - 3-5 bullet points - max 85 characters including spaces

- Physical and chemical properties of commercial raw milk studied throughout year

- Rennet clotting, ethanol stability and foaming ability displayed seasonal variation

- Significant interrelationships in physico-chemical properties were found 


\section{Introduction}

The composition of raw bulk milk is of prime importance for the manufacture of products in the UK, and there is significant interest in variations in the composition and physico-chemical properties of raw milk. In general, the composition of milk varies with season, stage of lactation, feeding, health status of the cow, milking interval, genetic factors and other day to day variation (Heck, van Valenberg, Dijkstra and van Hooijdonk, 2009).

The effects of seasonal variation on milk composition have been reported by many researchers and it is clear that the concentrations of many constituents and the physicochemical properties vary throughout the year to different extents (DairyCo, 2013). Heck et al., (2009) reported lower fat and protein contents in summer than in winter milk. This could be attributed to the different temperatures and feed composition, because cows consume more dry feed in winter, whereas in summer they eat grass and stay outside for longer (Fox and McSweeney, 2003). Some of this variation is well established and predictable. For example, DairyCo (2013) reported that in the years 2009 to 2013, fat levels from the UK national herd gradually decreased from January to July, followed by a sharp increase to more than $4.20 \%$ in August and September, and remained constant in October, November and December. Protein content followed a similar trend but with less variation. From November to April, protein content declined steadily from $3.35 \%$ to $3.23 \%$, followed by a constant period from April to July, and finally increased slightly from July to November. While these trends are repeated annually, it is notable that there was significant year on year variation in the absolute values. Also it should be noted that these trends are the means of the national herd, and greater variation would be expected when considering individual milk supplies. Different regions and feeding regimes result in different seasonal effects on the main components of raw milk. Compared with the UK, the lowest protein content observed by O'Brien, Mehra, 
49 Connolly and Harrington, (1999a) in Ireland was in March, which was probably due to lower intake of feed energy with indoor feeding.

These seasonal changes cause problems, but also allow opportunities for dairy manufacturers. For example, it is well established that butter spread ability is better when produced from summer fat compared with winter fat, due to the higher proportion of unsaturated fatty acids when cows are maintained on pasture in summer (Schmidt and Van Vleck, 1974). In the cheese industry, extended rennet clotting times can result in either disruption of production schedules or the failure to form a coagulum (Schmidt and Van Vleck, 1974). In addition to cheese manufacturing, seasonal variation in milk composition probably causes a range of problems in the manufacture of casein powder, whipping cream and liquid milk (Murphy and 59 O'Brien, 1997).

Variation in raw milk properties, such as $\mathrm{pH}, \mathrm{Ca}^{2+}$ and mineral content, can also have a pronounced effect on the manufacture of different dairy products (Faka, Lewis, Grandison and Deeth, 2009). For example, according to Faka et al., (2009), higher $\mathrm{Ca}^{2+}$ and lower $\mathrm{pH}$ was generally correlated with poor heat stability in skim milk powder (SMP) and vice versa, and it is well known that calcium chloride addition can reduce the rennet coagulation time and increase the curd firmness in cheese-making (Tsioulpas, 2005). On-Nom, Grandison and Lewis (2010) found that $\mathrm{Ca}^{2+}$ concentration increased as $\mathrm{pH}$ decreased, and both parameters

67 decreased as temperature increased. Casein micelle size, buffering capacity, viscosity and foaming ability are other important physico-chemical properties, which are related to the natural and induced variations in the composition of milk (Salaun, Mietton, and Gaucheron, 2005; Fox and McSweeney, 2003).

The aim of this study was to determine the composition and physical properties of raw milk from a commercial herd over the period from August 2011 to October 2012. Although seasonal variation in milk composition and properties has been studied previously, the current 
study is focussed on the practical relationship of these variations to dairy product manufacture.

\section{Materials and methods}

\subsection{Milk samples}

Raw bulk milk was collected from the University of Reading Centre for Dairy Research. The herd consists of an average of 550 lactating Holstein cows and the milk is sold commercially. The animals are year-round calvers, and the majority are maintained indoors on total mixed rations, while approximately $30 \%$ spend the summer months on grass. The composition and physical properties were measured every two weeks. All analyses of raw milk were carried out in triplicate. $\mathrm{pH}$, ionic calcium, lactose, protein, fat and total solids content, rennet clotting time (RCT), ethanol stability (ES), percentage of dry sediment, density, viscosity, buffering capacity (BC), casein micelle size, freezing point depression (FPD), foaming ability were measured at $20^{\circ} \mathrm{C}$ within 24 hours of milking. A total of 25 bulk milk samples were studied during the period August 2011 to October 2012.

\subsection{Chemical analysis}

The protein, fat, lactose, urea, somatic cell count (SCC) and total casein concentrations were measured in raw milk using a Lactoscope (Quadrachem Laboratories Ltd, London, UK)

pH was measured using a Sentron 3001 pH meter (Sentron Europe BV, ZH Roden, Dutch), which was calibrated with standard buffer solutions of $\mathrm{pH} 4.0$ and 7.0.

Ionic calcium $\left(\mathrm{Ca}^{2+}\right)$ was measured using a Ciba Corning $634 \mathrm{ISE} \mathrm{Ca}^{2+} / \mathrm{pH}$ analyser (CibaCorning Diagnostic Limited). The instrument was calibrated in the millivolt (mV) output mode with solutions of $0.50,1.00,2.50$ and $5.00 \mathrm{mM} \mathrm{Ca}^{2+}$ daily, prior to use. There was a 
97 linear relationship between $\log$ (ionic calcium) and $\mathrm{mV}$ output, with correlation coefficients

98 greater than 0.99 .

To determine total solids content (TS), raw milk samples ( $5 \mathrm{~g}$ ) were accurately weighed and poured into stainless aluminium dishes and placed in an oven $\left(100^{\circ} \mathrm{C}\right)$ to constant weight. The residual dry weight of raw milk was considered as the total solids.

To measure buffering capacity (BC), $4.0 \mathrm{~mL} 0.1 \mathrm{M}$ HCL solution was added to $25 \mathrm{~mL}$ raw milk sample and left for $1 \mathrm{~h}$ at room temperature. The $\mathrm{pH}$ difference before, and 1 hour after, acid addition was considered to be the buffering capacity, and was expressed in $\mathrm{pH}$ units. The fall in $\mathrm{pH}$ accompanied by this procedure is similar to the fall in $\mathrm{pH}$ when milk is heated from $20{ }^{\circ} \mathrm{C}$ to $120^{\circ} \mathrm{C}$.

Ash content was measured using the AOAC method (2005) employing a Precisa 125A balance. Dry ashing was preferred to wet digestion. Results were expressed as \% (w/v) percentage of ash in milk. Each sample was measured in triplicate.

Total calcium and magnesium concentration were determined according to the AOAC official method of analysis 991.25 (AOAC, 2005), employing a Pye Unicam SP9 Atomic Absorption Spectrophotometer (Atomic absorption Spectrometer novAA350, Analytik Jena AG, Germany) and using a calcium/magnesium lamp at a wavelength of $422.7 \mathrm{~nm}$ and 282.5 $\mathrm{nm}$ respectively. This method involves dry ingestion of milk samples followed by dissolution of the resulting ash in concentrated nitric acid $\left(69 \% \mathrm{HNO}_{3}\right.$, Fisher Scientific, Loughborough, UK). The calcium in the samples $(100 \mathrm{ml})$ reacts with the added lanthanum chloride solution, 1ml (10\%; Fisher Scientific, Loughborough, UK).

Total citrate concentration was determined by HPLC (High Performance Liquid Chromatography) according to Garnsworthy, Masson, Lock and Mottram (2006).The HPLC apparatus consisted of an Agilent 1100 Isocratic Pump, an auto-sampler, a variable 
121 wavelength detector, and a Prevail ${ }^{\mathrm{TM}}$ Organic Acid, $5 \mu \mathrm{m}$ Column $(150 \times 4.6 \mathrm{~mm})$ (Alltech,

122 Deerfield, US). Data were analysed by ChemStation software.

123 Total phosphorus concentration was determined according to IDF standard 42B (International

124 Dairy Federation, 1990).

$125 \quad 2.3$ Physical analysis

126 Dry sediment and ethanol stability (ES) were measured according to Chen, Grandison and 127 Lewis, (2012).

128 A range of hydrometers (ranged from 1.000 to $1.050 \mathrm{~g} / \mathrm{ml}$ ) were used to determine the 129 density of raw milk.

130 Kinematic viscosity was determined by a capillary BS/U tube viscometer (PoultenSelfe and Lee Ltd., Essex, UK). Raw milk was well shaken before the analysis. All measurements took place at room temperature $\left(20^{\circ} \mathrm{C}\right)$. The kinematic viscosity was calculated by multiplying the flow time by the instrument constant. Types B, C, and D BS/U tube viscometers were used.

134 The nominal constants for each type are $0.01,0.03$ and $0.1 . \mathrm{cSt} \mathrm{s}^{-1}\left(1 \mathrm{cSt} \mathrm{s}^{-1}=10^{-6} \mathrm{~m}^{2} \mathrm{~s}^{-1}\right)$ 135 respectively. Freezing point depression (FPD) was measured for milk samples by using an Advanced Milk 137 Cryoscope 4L2 (Advance Instruments Inc., Metuchen, NJ, USA). Rennet coagulation time (RCT) was measured according to Tsioulpas (2005). The average casein micelle size of raw milk was measured with a Zeta Master (Malvern Instruments, Malvern, UK) according to Chen et al., (2012).

141 Foaming ability was determined at $65^{\circ} \mathrm{C}$ by the air bubbling method developed by Huppertz 142 (2010).

\subsection{Statistical analysis}


Sciences (SPSS 18) software. All variables were centred and normalised using SPSS 18 normality test (explore). The Spearman correlation method in Xlstat was used to establish whether the correlation coefficients between parameters were significant. Mean values, number of determinations, regression, univariate analysis and seasonal variations were calculated using SPSS 18 one-way ANOVA. The threshold levels of significance of $p<0.05$, 0.01 and 0.001 were used in all analysis. Seasonal variations in raw milk were categorised into four groups as shown in Table 1.

Measurements were made in triplicate and inserted into the database. Principal component analysis (PCA) statistical method was performed with the Xlstat, 2012 software.

\section{Results and discussion}

The milk samples were analysed in detail in order to investigate how milk composition varies throughout the year. The milk was also processed under standardised conditions to make a variety of dairy products in order to investigate how selected quality attributes of these products are influenced by milk composition. This paper presents the results for properties of the raw milk.

\subsection{Chemical properties of raw milk}

Table 2 presents the average values, range and seasonal variation for composition of raw milk collected over the period August 2011 to October 2012. Higher total solids were found in autumn than in summer but there was no significant seasonal variation over the spring and winter. It was observed by O'Brien et al., (1999a) that there was a reduction in total solids content in January to April and July to August which is in agreement with the current study. Raw milk produced in the autumn period had a significantly higher fat content than in other periods which is broadly in line with the UK national statistics (DairyCo, 2013). 
Compared with fat, the protein and casein concentrations showed less variability, ranging from 2.89 to $3.56 \%$. However, significantly higher protein content was observed in spring compared to the summer and autumn periods. This would not be expected from UK national statistics (DairyCo, 2013), which would predict higher levels of protein in the autumn and winter months, and may reflect the particular feeding regime used for this herd.

The average concentration of urea was $3.95 \mathrm{mM}$, ranging from $2.65 \mathrm{mM}$ in October to 5.44 $\mathrm{mM}$ in November, although there was no specific significant seasonal variation. There were no significant correlations between urea and other components of raw milk. This contrasts with Giaccone, Todaro and Scatassa (2007) who reported considerable seasonal variation in urea level. This difference could be attributed to the farming methods used at the Reading University farm where there was no strict time schedule in moving from indoor feeding to pasture feeding.

There was a little variation in the level of lactose which ranged from 4.52 to $4.69 \%$ with no significant seasonal differences. This is not surprising as lactose is well known to be one of the least variable milk components.

$\mathrm{pH}$ showed a similar seasonal trend to the protein, which was significantly higher in spring than in summer and autumn. However, buffering capacity (BC) did not display any significant seasonal trend.

Generally the levels of minerals and citrate were within the normal range found for cows' milk, and while there were fluctuations, there were no significant differences between seasons. The total calcium and magnesium concentrations followed a similar trend. This is in general agreement with O'Brien, Mehra, Connolly and Harrington (1999d) who showed that calcium, magnesium and chloride concentrations fluctuated considerably but showed no definite trend over the year, and that these minerals were predominantly influenced by 
lactation stage, but were also influenced by feed type (Keogh, Kelly, O'Keeffe and Phelan, 1982).

The ash content for raw milk fluctuated greatly over the period of study, but no significant seasonal difference was observed. The maximum ash content $(1.03 \%)$ was observed in August and minimum content $(0.53 \%)$ was found in October. Rao and Mishra (2010) reported that ash content was not significantly influenced by season, breed and lactation stage, but much narrower variations were observed compared to the current study.

The $\mathrm{Ca}^{2+}$ concentration ranged from 1.68 to $2.55 \mathrm{mM}$ (which corresponds to 5.7 to $8.7 \%$ of the total $\mathrm{Ca}$ ), with no significant seasonal differences. Although bulking of milk will reduce these variations, raw milk destined for processing will still be subject to considerable variations in $\mathrm{Ca}^{2+}$ and $\mathrm{pH}$, which may have significant effects on its processing behaviour. Grimley, Grandison and Lewis (2009) monitored changes in minerals throughout the spring flush period and reported that $\mathrm{Ca}^{2+}$ was reduced from 1.48 to $1.40 \mathrm{mM}$ at this time, whereas total divalent cations were reduced from 35.4 to $33.4 \mathrm{mM}$. There was no evidence to suggest that any of the milk samples were unsuitable for processing, in terms of poor heat stability or poor coagulation properties.

Buffering capacity (BC) of raw milk was constant throughout the year. The average value of

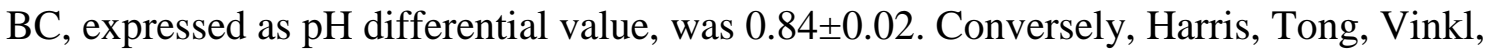
Izeol and Jimenez-Flores (2002) observed that the highest BC values were found in December and the lowest in September in California, using a method based on titration of milk to $\mathrm{pH}$ 4.0. Again, farming methods and feeding regime probably contributed to differences in the study.

The BC depends mainly on the composition and distribution of minerals and proteins between aqueous and solid phases. Salaun et al., (2005) proposed that BC is determined by 
soluble phosphate, colloidal calcium phosphate, citrate, bicarbonate, caseins and whey

217 proteins. However, with the exception of a positive correlation with somatic cell count, no significant correlation between $\mathrm{BC}$ and compositional properties was observed in the current study.

\subsection{Physical properties of raw milk}

221

222

224

Values, ranges and seasonal variations in physical properties and various markers of milk stability are given in table 3 . The viscosity and density displayed some fluctuations but no significant seasonal variation.

The average casein micelle size was $163 \mathrm{~nm}$, which was slightly smaller than reported by Glantz, Devold, Vegarud, Lindmark Månsson, Stålhammar and Paulsson (2010).The range was from $132 \mathrm{~nm}$ in August to $202 \mathrm{~nm}$ in October. However, no significant seasonal variation was observed. Holt and Muir (1978) reported that the average size of casein micelles followed a pronounced seasonal trend with smaller average sizes in summer compared to winter. The present study showed a similar trend in that the average sizes in summer and winter were $162 \mathrm{~nm}$ and $167 \mathrm{~nm}$ respectively, but the difference was not statistically significant.

The FPD displayed a relatively narrow range, as would be expected because it is a consequence of the osmotic balance between the milk and the blood (Shipe, 1959). However the values were significantly greater in winter than in the spring and summer. Changes in temperature and diet are considered to be primarily responsible for the seasonal effect on milk FPD (Henno, Ots, Jõudu, Kaart and Kärt, 2008). However, the latter authors stated that the increase in milk freezing point was not caused by the lack of energy or protein from the feed ration, but was probably due to the increased water intake due to the increased temperature and sunshine hours as suggested by Bjerg, Rasmussen and Nielse (2005). 
240 The RCT, ES, foaming ability and sediment formation are all properties which relate directly

241 to the processing of milk, and it is notable that all displayed significant seasonal variation

242 (Table 3). The raw milk samples produced in spring had significantly longer RCT than in the 243 autumn. Average values were $21 \mathrm{~min}$ in spring compared to $17 \mathrm{~min}$ in autumn, which would 244 imply considerable coagulation time differences in rennet cheese manufacturing. This variation could be attributed to the $\mathrm{pH}$ value in raw milk. It is well known that reduced $\mathrm{pH}$ leads to a reduction in RCT. (e.g. Lucey, 2002).

247 The average ES was higher (93\%) than that reported by Chavez, Negri, Taverna and Cuatrin 248 (2004), where about one third of samples had an ES less than 72\%. All samples were above $74 \%$, which is the suggested limiting value for for UHT processing (Shew, 1981). Ethanol stability followed the same seasonal trend as RCT with significantly higher values in spring 251 than autumn.

252 Dry sediment formation followed a different trend with significantly higher values in the summer and autumn compared to the winter. However, the importance of this finding is not 254 clear as sediment in raw milk may be unrelated to other compositional properties, being at least partly related to extraneous debris in the milk (reference).

256 Foaming ability displayed the greatest range of all parameters measured (8.5 times difference) 257 and in common with the RCT and ES, values were highest in the spring, in this case higher than the other three seasons. (discussed in section 3.3.7) 
261 Significant correlations between the main milk components and properties are shown in

262 Tables 4 and 5. It should be noted that not all the significant correlations will be causal, some

263 may be coincidental or linked indirectly to other parameters.

264 Fat content was strongly correlated with total solids, $\mathrm{pH}$ and protein content, and weakly with

265 total calcium and phosphorus, while protein content was significantly correlated with $\mathrm{pH}$ and 266 total casein content.

267 The average value of total solids was $12.78 \%$ which gave a strong positive correlation 268 coefficient $(p<0.001)$ to the fat content as shown in Table 4. Also, it was weakly correlated 269 with total ash and calcium content.

270 Lactose content was weakly correlated with total ash, citrate and SCC content.

271 As shown in Table 4, there were positive correlations between $\mathrm{pH}$ and protein and total 272 casein content, but a negative correlation with fat content. Pastorino, Hansen and McMahon 273 (2003) reported that the most significant effect of decreased $\mathrm{pH}$ was to promote mineral 274 solubilisation and casein dissociation from casein micelles, both of which altered milk 275 properties by affecting the extent and nature of protein interactions.

276 A weak but significant negative correlation between $\mathrm{pH}$ and $\mathrm{Ca}^{2+}$ was found, which agrees 277 with On-Nom et al., (2010). It is well established (Fox and McSweeney, 2003) that reducing 278 milk pH results in solubilisation of micellar calcium, which would result in increased $\mathrm{Ca}^{2+}$.

279 Keogh et al., (1982) reported that there were significant positive correlations between citric 280 acid and fat content and between soluble calcium and fat content, but no correlation was 281 found between fat content and citrate in the present study.

282 A number of weak but significant correlations were found among the mineral, citrate, lactose and SCC concentrations, but it is not clear which of these were of biological significance. 
RCT and ES were strongly positively correlated, which is not surprising as both are expressions of the stability of the casein micelle system (Tsioulpas, 2005). Both parameters were significantly related to $\mathrm{pH}$, protein, casein and fat levels. The correlations with fat are likely to be coincidental or linked indirectly to other parameters. The correlations with $\mathrm{pH}$ are to be expected as lowering $\mathrm{pH}$ is known to reduce casein micelle stability and the relationships with protein and casein are probably at least partly secondary to the relationships with $\mathrm{pH}$ (Fox and McSweeney, 2003). RCT correlated with $\mathrm{Ca}^{2+}$, and it is surprising that ES did not display a similar correlation, as other researchers (e.g. Davis and White, 1958) have reported that ethanol stability was inversely related to $\mathrm{Ca}^{2+}$ concentration. The explanation could be that ES was not only very high for this sample set but the range was also much narrower than those found by other investigators. Also ES was only measured up to $100 \%$, and a number of samples displayed ES values of $100 \%$ (N.B. it is possible to have values $>100 \%$ if more concentrated ethanol solutions are used).

\subsubsection{Rennet Clotting Time (RCT)}

RCT was highly positively correlated with $\mathrm{pH}$, protein, casein and $\mathrm{ES}$, but negatively correlated with $\mathrm{Ca}^{2+}$, fat and total phosphorus content (Table 5). The strong positive correlation with $\mathrm{pH}$ would be expected from earlier studies. Lucey (2002) showed that the activity of rennet increased with decrease of $\mathrm{pH}$, while other studies have demonstrated that the aggregation of destabilised micelles increases at lower $\mathrm{pH}$ due to solubilisation of micellar calcium phosphate, a decrease in net surface charge and dissociation of casein from the micelles (Fox and McSweeney, 2003). The $\mathrm{Ca}^{2+}$ was negatively correlated with RCT, in agreement with Tsioulpas (2005) who showed that increasing $\mathrm{Ca}^{2+}$ would accelerate milk coagulation because $\mathrm{Ca}^{2+}$ in the serum phase reduces the negative charge on the surface of 
casein micelles, weakening repulsion and accelerating their coagulation. Fox and McSweeney (2003) suggested that initiating coagulation required a minimum concentration of $\mathrm{Ca}^{2+}$ of about $1.5 \mathrm{mM}$.

Jõudu, Henno, Kaart, Püssa and Kärt (2008) showed that an increase in milk protein, casein, casein fractions, and the casein number decreased the rennet coagulation time of milk which was not in agreement with the current study. The weak negative correlation between RCT and fat content observed in Table 5 is probably secondary to the correlations of fat with $\mathrm{pH}$ and protein (Table 4).

The negative correlation of RCT with total phosphorus content corresponds with the findings of McMahon, Brown, Richardson and Ernstrom (1984) who found that addition of phosphate reduced coagulation time with a minimum at $0.01 \mathrm{M}$ added phosphate. However higher levels of addition (0.04 M added phosphate) increased coagulation time above control levels. They suggested that the calcium phosphate system was extremely slow in equilibrating, and at low added phosphate, it enhanced coagulation, whereas at high phosphate the equilibrium was forced sufficiently in the direction of complex formation with $\mathrm{Ca}^{2+}$ that coagulation was retarded.

There was a significant positive correlation between RCT and ES, which could be attributed to $\mathrm{Ca}^{2+}$ and $\mathrm{pH}$ in raw milk because higher concentration of $\mathrm{Ca}^{2+}$ and lower $\mathrm{pH}$ value resulted in the shorter RCT and poor ES in raw milk as described above.

\subsubsection{Casein micelle size}

As discussed previously, large casein micelles would be expected to cause a longer RCT, poorer heat stability (Chen et al., 2012) and weaker curd compared with smaller ones. As 
shown in Table 4, there was a positive significant correlation between casein micelle size and total phosphorus content. Holt and Muir (1978) reported that the average size of casein micelles correlated positively with the amount of colloidal phosphorus per unit weight of casein, and negatively with casein-bound calcium. Micelle size has been shown to vary, not only between feeding regimens and regions (Devold, Brovold, Langsrud and Vegarud, 2000), but also between protein genotypes in different breeds. The casein micelle size was also related to milk $\mathrm{pH}$ (table 5). Milk pH correlated negatively with casein micelle size, implying that a higher milk $\mathrm{pH}$ would result in smaller native casein micelles, which was in contrast to data of Glantz et al., (2010), although the reason for this disparity is not clear. With the exception of total phosphorus content, none of the mineral components was significantly related to casein micelle size, which is also in contrast to Glantz et al., (2010). Total protein content was significantly correlated to the casein micelle size, which is in agreement with results found previously in individual cows (Devold et al., 2000). The fact that there was no correlation with the total calcium content was also in agreement with studies on bulk tank milk and milk from individual cows (Devold et al., 2000).

\subsubsection{Viscosity and density}

The average value of viscosity of was $1.93 \mathrm{cSt}\left(1 \mathrm{cSt}=10^{-6} \mathrm{~m}^{2} \mathrm{~s}^{-1}\right)$, with a range from 1.52 to $2.36 \mathrm{cSt}$ (Table 3). It has been shown by Fernandez-Martin (1972) that at room temperature, milk viscosity increased either with increasing fat content, when solids-not-fat content was kept constant, or with increasing solids-not-fat content when fat content was constant. There is general agreement that milk viscosity is a non-linear function of total solids content. However, according to Table 5 , viscosity was highly significantly positively correlated with 
$\mathrm{pH}$ and casein content, but not with total solids or fat content, although the correlation with $\mathrm{pH}$ may be secondary to that with casein.

According to Table 2, the highest density was $1.031 \mathrm{~g} / \mathrm{ml}$ and the lowest was $1.026 \mathrm{~g} / \mathrm{ml}$, which fall within the normal range of $1.025-1.035 \mathrm{~g} / \mathrm{ml}$, reported by Scott, Robinson and Wilbey (1998). The density of raw milk did not vary significantly with seasonal changes over the year.

\subsubsection{Somatic Cell Counts (SCC)}

Contrary to the reports of some authors (Klinkon, Zadnik and Nemec, 2000), the raw milk produced in winter had significantly more SCC than in other seasons, presumably reflecting differences in herd management. The SCC results of Rajčević, Potočnik and Levstek (2003) were in partial agreement with the current study. SCC in raw milk ranged from 65000 to 357000 and correlated positively and significantly with lactose and phosphorus content, and negatively with total calcium and citrate content in raw milk in the present study.

Rajčević et al., (2003) reported that a statistically significant negative correlation occurred between SCC and lactose content in milk, which was in contrast to the present study.

Compared with former researchers, the significant positive correlation in our results could be attributed to the different feed, regions and even milking methods.

\subsubsection{Freezing Point Depression (FPD)}

372 Freezing point depression was significantly higher in winter than in spring and summer

373 (Table 3) with a range comparable to that reported by Shipe (1959) - i.e. 515 to $530 \mathrm{~m}^{\circ} \mathrm{C}$.

374 Changes in temperature and diet were considered to be primarily responsible for the seasonal effect on milk FPD (Henno et al., 2008). Pinkerton and Peters (1958) suggested that differences in environmental temperature and animal feed were contributing factors to the 
seasonal variations that they observed. However, Henno et al., (2008) pointed out that the increase in milk FPD was not caused by the lack of energy or protein from the feed ration used but was probably due to the increased water intake with increased temperature and sunshine hours. No significant correlation between FPD and compositional parameters was found, which implies that FPD was a strong independent parameter in raw milk. The freezing point of cows' milk is relatively constant as a consequence of osmotic equilibrium in milk and blood (Shipe, 1959).

\subsubsection{Foaming ability}

The foaming ability (the time to produce a foam) of raw milk in the summer period was significantly lower than in spring, autumn and winter (Table 3). It was significantly positively correlated with protein and casein content in raw milk (Table 5) which suggests that higher protein content in raw milk would cause the longer foaming times. This result is counterintuitive and contrasts with Marinova et al., (2009) who reported that the foaming ability of milk increased with the protein concentration, until a constant value was reached.

Foaming ability did not correlate significantly with milk $\mathrm{pH}$, although the $\mathrm{pH}$ range was narrow. However, Augustin and Clarke (2008) indicated that when $\mathrm{pH}$ was decreased to 5.6, an increase in foaming ability was observed, but this $\mathrm{pH}$ is well below the values measured in the current study.

The mineral components in milk presumably play a significant part in determining the foaming ability properties due to their large effect on the casein micelle (Augustin and Clarke, 2008). However, no correlation was observed in the present study. Augustin and Clarke (2008) reported that addition of calcium chelators, such as citrate and EDTA, could improve 
the foaming ability and stability in milk. Such enhanced foaming ability in milk could possibly be attributed to the higher proportion of non-micellar casein, which could adsorb onto the air interface.

Gambini, Castagnetti and Losi (1995) reported that foaming capacity of milk also tended to decrease with increasing SCC due to the strongly correlated with increased plasmin concentration and proteolysis in milk. However, no significant relation was observed in the present study.

\subsubsection{Principal Component Analysis}

PCA was carried out on the whole data set consisting of 25 samples and the 23 variables. The similarity map defined by principal components PC 1 and PC 2 showed a discrimination of samples according to the different seasons. Considering the PCA similarity map defined by principal components 1 and 2, the milk samples were separated according to principal component 1 (37.79\% of the total variance; Figure 1$)$. This component clearly showed the effect of the seasonal variations. Most samples in spring and summer were located on the positive part of the similarity map, whereas autumn samples were on the negative part. Raw milk in spring and summer were characterised by higher $\mathrm{pH}$, ash content, foaming ability, ES, $\mathrm{RCT}$, total casein and protein content. In contrast, the properties of raw milk in autumn were characterised by higher fat content and CM size than in spring and summer. Autumn milk also exhibited higher $\mathrm{Ca}^{2+}$, urea, TS, SCC and percentage of dry sediment than spring and summer milk, but the contributions of these variables were less significant. Similarly, spring milk contained higher citrate, total $\mathrm{Mg}$, Total $\mathrm{Ca}$ and viscosity, but these attributes were less significant due to being closer to the origin of the coordinate. BC, total phosphorus, density and lactose were not subject to seasonal variations, since these variables were located close to the origin of the coordinate (Figure 1) which is in agreement with Table 2 and 3. However, 
424 FPD was not influenced by seasonal variations from the similarly map which was in contrast

425 to Table 3 which, again, implied that FPD was a strong independent parameter in raw milk.

426 In addition, two summer milk samples located in the bottom left position could probably be

427 attributed to the sampling time since they were the final samples in summer period. This short

428 interval between the last sample in summer and the first sample in autumn probably explains

429 the similar physico-chemical properties. Overall this analysis shows that the physico-

430 chemical properties of the spring and autumn milks were quite distinct, whereas the summer

431 and winter milks were much less differentiated.

\section{4. General Discussion}

433 The aim of this study was to determine the extent of variations in composition and physicochemical properties of bulk milk from a commercial herd in the UK throughout the year.

435 Seasonal variations were found for some properties and correlations between some physical 436 properties and milk composition have been highlighted. PCA was used to distinguish between the samples and was able to differentiate between autumn and spring milk samples.

438 The novelty of this study is that these milk samples were then used to produce a range of products under standardised conditions in order to determine how selected quality attributes of the products were influenced by milk composition and other properties.

442 The observed variation in different parameters could be related to seasonal effects in some 443 cases but seemed to be more difficult to explain. Much of the data was consistent with earlier studies on seasonal variation, while other parameters varied less widely or displayed less seasonality than may have been expected.. This may be because previous studies were from 
different geographical areas, or employed different, in some cases outdated, farming practices such as diets or calving patterns.

Many interrelationships in physical and chemical parameters were observed and it is clear that the milk supply would be more suited to the manufacture of different products at different times of the year or even on a day to day basis. Subsequent studies will report on variation in production and quality of products manufactured from the same milk samples described in the current study. In this way it is hoped to provide some clearer guidelines on the relationships in milk composition, properties and product manufacture, including seasonal factors.

\section{References}

AOAC (2005). Moisture in dried milk. In Official Methods of Analysis 727.05 (18 $\left.{ }^{\text {th }} \mathrm{ed}\right)$. USA: AOAC International Augustin, M. A., \& Clarke, P. T. (2008). Skim milk powders with enhanced foaming and steam-frothing properties. Dairy Science and Technology, 88, 149-161.

460 Chavez, M. S., Negri, L. M., Taverna, M. A., \& Cuatrin, A. (2004). Bovine milk composition parameters affecting the ethanol stability. Journal of Dairy Research, 71, 201-206. Chen, B. Y., Grandison, A. S., \& Lewis, M. J. (2012). Comparison of heat stability of goat milk subjected to ultra-high temperature and in-container sterilization. Journal of Dairy

464 Science, 95, 1057-1063.

465 DairyCo. Market information, Supply \& Production, 2013. URL http://www.dairyco.org.uk/market-information/supply-production/composition-andhygiene/uk-milk-composition/ Accessed 04.04.2013.

468 Davies, D. T., \& White, J. C. D. (1958). The relation between the chemical composition of 469 milk and the stability of the caseinate complex: II. Coagulation by ethanol. Journal of Dairy 470 Research, 25, 256-266.

471 Devold, T. G., Brovold, M. J., Langsrud, T., \& Vegarud, G. E. (2000). Size of native and 472 heated casein micelles, content of protein and minerals in milk from Norwegian Red Cattle- 
473 effect of milk protein polymorphism and different feeding regimes. International Dairy

474 Journal, 10, 313-323.

475 Faka, M., Lewis, M. J., Grandison, A. S., \& Deeth, H. (2009). The effect of free $\mathrm{Ca}^{2+}$ on the 476 heat stability and other characteristics of low-heat skim milk powder. International Dairy

477 Journal, 19, 386-392.

478 Fernandez-Martin, F. (1972). Influence of temperature and composition on some physical

479 properties of milk and milk concentrates. II. Viscosity. Journal of Dairy Research, 39, 75-82.

480 Fox, P.F \& McSweeney, P. L. H. (2003). Advanced Dairy Chemistry, volume 1, proteins. (3 ${ }^{\text {rd }}$

481 ed). London: Kluwer Academic/ Plenum Publishers.

482 Gambini, G., Castagnetti, G. B., \& Losi, G. (1995). Influence of somatic cell count and heat 483 treatments on milk foam formation and stability. Industrie Alimentari. 34, 247-252.

484 Garnsworthy, P. C., Masson, L. L., Lock, A. L., \& Mottram, T. T. (2006). Variation of milk 485 citrate with stage of lactation and de novo fatty acid synthesis in dairy cows. Journal of Dairy 486 Science, 89, 1604-1612.

487 Giaccone, P., Todaro, M., \& Scatassa, M. L. (2010). Factors associated with milk urea 488 concentrations in Girgentana goats. Italian Journal of Animal Science, 6, 622-624.

489 Glantz, M., Devold, T. G., Vegarud, G. E., Lindmark Månsson, H., Stålhammar, H., \& 490 Paulsson, M. (2010). Importance of casein micelle size and milk composition for milk 491 gelation. Journal of Dairy Science, 93, 1444-1451.

492 Grimley, H., Grandison, A., \& Lewis, M. (2009). Changes in milk composition and 493 processing properties during the spring flush period. Dairy Science and Technology, 89, 405494416.

495 Harris, A., Tong, P., Vinkl, S., Izeol, J., \& Jimenez-Flores, R., J. (2002). Effects of seasonal 496 and regional variations in milk components on the buffering capacity of milk in California. 497 Journal of Dairy Science, 85, 289.

498 Heck, J. M. L., Van Valenberg, H. J. F., Dijkstra, J., \& Van Hooijdonk, A. C. M. (2009). 499 Seasonal variation in the Dutch bovine raw milk composition. Journal of Dairy Science, 92, $500 \quad 4745-4755$.

501 Henno, M., Ots, M., Jõudu, I., Kaart, T., \& Kärt, O. (2008). Factors affecting the freezing 502 point stability of milk from individual cows. International Dairy Journal, 18, 210-215.

503 Holt, C., \& Muir, D. D. (1978). Natural variations in the average size of bovine casein 504 micelles. II. Milk samples from creamery bulk silos in south west Scotland. Journal of Dairy 505 Research, 45, 347-353. 
Huppertz, T. (2010). Foaming properties of milk: a review of the influence of composition and processing. International Journal of Dairy Technology, 63, 477-488.

IDF. (1990). Milk: determination of total phosphorus content by the spectrometric method. In International Dairy Federation standard No 42B. Brussels, Belgium: IDF. Jõudu, I., Henno, M., Kaart, T., Püssa, T., \& Kärt, O. (2008). The effect of milk protein contents on the rennet coagulation properties of milk from individual dairy cows. International Dairy Journal, 18, 964-967.

Karoui R., Mazerolles G., \& Dufour E., (2003). Spectroscopic techniques coupled with chemometric tools for structure and texture determinations in dairy products. International Dairy Journal, 13, 607-620.

Keogh, M. K., Kelly, P. M., O'Keeffe, A. M., \& Phelan, J. A. (1982). Studies of Milk Composition and Its Relationship to Some Processing Criteria: II. Seasonal variation in the mineral levels of milk. Irish Journal of Food Science and Technology, 13-27.

Klinkon, M., Zadnik, T., \& Nemec, M. (2000). The impact of breeding, breed, successive lactation, stage of lactation, season and somatic cell count on basic milk components. Slovenian Veterinary Research, 37, 197-208.

Lucey, J. A. (2002). Formation and physical properties of milk protein gels. Journal of Dairy Science, 85, 281-294.

Marinovaa, K. G., Bashevaa, E.S., Nenovaa, B., Temelskaa, M.,Mirarefib, A.Y., Campbellb, B., \& Ivanova, I.B. (2009). Physico-chemical factors controlling the foam ability and foam stability of milk proteins: Sodium caseinate and whey protein concentrates. Food Hydrocolloids, 23, 1864-1876.

McMahon, D. J., Brown, R. J., Richardson, G. H., \& Ernstrom, C. A. (1984). Effects of calcium, phosphate, and bulk culture media on milk coagulation properties. Journal of Dairy Science, 67, 930-938.

Murphy, J. J., \& O'Brien, B. (1997). Quality milk for processing? The production technology. Proceedings of National Dairy Conference, Teagasc, Dublin, 54-83.

O'Brien, B., Mehra, R., Connolly, J. F., \& Harrington, D. (1999a). Seasonal variation in the composition of Irish manufacturing and retail milks: 1 . Chemical composition and renneting properties. Irish Journal of Agricultural and Food Research, 38, 53-64. 
536 O'Brien, B., Mehra, R., Connolly, J. F., \& Harrington, D. (1999d). Seasonal variation in the 537 composition of Irish manufacturing and retail milks: 4. Minerals and trace elements. Irish 538 Journal of Agricultural and Food Research, 38, 87-99.

539 On-Nom, N., Grandison, A. S., \& Lewis, M. J. (2010). Measurement of ionic calcium, pH, 540 and soluble divalent cations in milk at high temperature. Journal of Dairy Science, 93, 515541523.

542 Pastorino, A. J., Hansen, C. L., \& McMahon, D. J. (2003). Effect of pH on the chemical 543 composition and structure-function relationships of Cheddar cheese. Journal of Dairy Science, $54486,2751-2760$.

545 Pinkerton, F., \& Peters, I. I. (1958). Conductivity, per cent lactose, and freezing point of milk. 546 Journal of Dairy Science, 41, 392-397

547 Rajčević, M., Potočnik, K., \& Levstek, J. (2003). Correlations between somatic cells count 548 and milk composition with regard to the season. Agriculturae Conspectus Scientificus (ACS), $54968,221-226$.

550 Rao, A., \& Mishra, S. (2010). An assessment of the nutritional profile of milk in different 551 seasons and locations in Varanasi through modern laboratory techniques. Indian Journal of 552 Preventive and Social Medicine, 41, 237-239.

553 Salaün, F., Mietton, B., \& Gaucheron, F. (2005). Buffering capacity of dairy products. 554 International Dairy Journal, 15, 95-109.

555 Schmidt, G. H., \& Vleck, L. V. (1974). Principles of dairy science. WH Freeman and 556 Company. USA.

557 Scott, R., Robinson, R. R. K., \& Wilbey, R. A. (1998). Cheesemaking practice. ( $3^{\text {rd }}$ ed). 558 Springer.

559 Shew, D. I. 1981. IDF Bulletin, New monograph on UHT milk, document 133, Brussels, 115560121.

561 Shipe, W. F. (1959). The freezing point of milk. A review. Journal of Dairy Science, 42, 562 1745-1762.

563 Tsioulpas, A (2005) Role of minerals on casein micelle stability of bovine milk. Ph.D. Thesis. 564 Reading University. 


\begin{tabular}{lllc}
\hline Seasons & & Definitions & Sample size \\
\hline Spring & SP & March, April and May & 6 \\
Summer & SM & June, July and August & 6 \\
Autumn & A & September, October and November & 9 \\
Winter & W & December, January and February & 4 \\
\hline
\end{tabular}

565 Table 1 The definition and sample sizes of different seasons 


\begin{tabular}{llll}
\hline Compositional Properties & Mean+SD & Range & Seasonal variation \\
\hline $\mathrm{pH}$ & $6.79 \pm 0.35$ & $6.73-6.87$ & SP $>$ SM and A;W $>$ A \\
$\mathrm{Ca}^{2+}(\mathrm{mM})$ & $2.05 \pm 0.25$ & $1.68-2.55$ & NS \\
$\mathrm{TS}(\%)$ & $12.78 \pm 0.29$ & $12.31-13.31$ & $\mathrm{~A}>\mathrm{SM}$ \\
Protein $(\%)$ & $3.29 \pm 0.16$ & $2.89-3.56$ & $\mathrm{SP}>\mathrm{SM}$ and A \\
Total casein $(\%)$ & $2.36 \pm 0.09$ & $2.08-2.52$ & $\mathrm{SP}>\mathrm{SM}$ and A \\
Fat $(\%)$ & $4.08 \pm 0.36$ & $3.62-4.77$ & $\mathrm{~A}>\mathrm{SP}, \mathrm{SM}$ and W \\
Lactose $(\%)$ & $4.59 \pm 0.44$ & $4.52-4.69$ & $\mathrm{NS}$ \\
$\mathrm{BC}$ & $0.84 \pm 002$ & $0.78-0.88$ & $\mathrm{NS}$ \\
Ash $(\%)$ & $0.71 \pm 0.14$ & $0.53-1.03$ & $\mathrm{NS}$ \\
Total Ca $(\mathrm{mM})$ & $29.3 \pm 1.78$ & $24.5-31.5$ & $\mathrm{NS}$ \\
Total Mg $(\mathrm{mM})$ & $5.11 \pm 0.34$ & $4.21-5.81$ & $\mathrm{NS}$ \\
Total P $(\mathrm{mM})$ & $9.04 \pm 0.53$ & $8.22-10.1$ & $\mathrm{NS}$ \\
Total Citrate $(\mathrm{mM})$ & $27.5 \pm 2.12$ & $22.6-33.6$ & $\mathrm{NS}$ \\
Urea $(\mathrm{mM})$ & $3.95 \pm 0.40$ & $2.65-5.44$ & $\mathrm{NS}$ \\
SCC $\left(\mathrm{cells} \mathrm{ml}{ }^{-1} \times 10^{3}\right)$ & $155 \pm 63$ & $65-357$ & W $>$ SP, SM and A \\
\hline
\end{tabular}

Table 2 Composition of raw milk collected over the period August 2011 to October 2012 (Results are mean \pm Standard deviation, $\mathbf{n}=25$.)

$S P=$ Spring; $S M=$ Summer $; A=$ Autumn; $W=$ Winter $; N S=$ Non-significant difference $(p<0.05)$

566 Total solids=TS; Buffering capacity $=B C$; Somatic cell count $=S C C$ 


\begin{tabular}{llll}
\hline Physical properties & Mean+SD & Range & Seasonal variation \\
\hline Density $\left(\mathrm{g} / \mathrm{cm}^{3}\right)$ & $1.028 \pm 0.01$ & $1.026-1.031$ & $\mathrm{NS}$ \\
Casein micelle size (d.nm) & $163 \pm 16$ & $132-202$ & $\mathrm{NS}$ \\
$*$ Viscosity $(\mathrm{cSt})$ & $1.93 \pm 0.21$ & $1.52-2.36$ & $\mathrm{NS}$ \\
FPD $\left(\mathrm{m}^{\circ} \mathrm{C}\right)$ & $523 \pm 3$ & $514-530$ & $\mathrm{~W}>\mathrm{SP}$ and SM \\
Foaming ability (s) & $88 \pm 47$ & $24-205$ & $\mathrm{SP}>\mathrm{SM}$ A and W \\
RCT $(\mathrm{min})$ & $18.6 \pm 3.1$ & $12.3-24.0$ & $\mathrm{SP}>\mathrm{A}$ \\
ES \% & $93 \pm 5$ & $84-100$ & $\mathrm{SP}>\mathrm{A}$ \\
Sediment $(\%)$ & $0.09 \pm 0.02$ & $0.03-0.13$ & $\mathrm{SM}$ and A $>\mathrm{W}$ \\
\hline
\end{tabular}

$* 1 \mathrm{cSt}=10^{-6} \mathrm{~m}^{2} \mathrm{~s}^{-1}$

Table 3 Physical and stability properties of raw milk over the period August 2011 to October 2012 (Results are mean \pm Standard deviation, $\mathbf{n = 2 5}$.)

$S P=$ Spring; SM=Summer; $A=$ Autumn; $W=$ Winter $; S=$ Non-significant difference $(p<0.05)$

567 Freezing point depression $=F P D ;$ Rennet coagulate time $=R C T$; Ethanol stability $=E S$ 


\begin{tabular}{ll}
\hline Components & Correlation coefficient $(\boldsymbol{p})$ \\
\hline $\mathrm{pH} / \mathrm{Ca}^{2+}$ & $\mathbf{- 0 . 4 7 1} *$ \\
pH/Protein & $\mathbf{0 . 6 3 1} * * *$ \\
pH/Total casein & $\mathbf{0 . 6 5 8 * * *}$ \\
pH/Fat & $\mathbf{- 0 . 5 2 5 * *}$ \\
TS/Fat & $\mathbf{0 . 6 3 0 * * *}$ \\
TS/Total Ca & $\mathbf{- 0 . 4 0 6 *}$ \\
TS/Total ash & $\mathbf{0 . 4 8 2}$ \\
Protein/Fat & $\mathbf{- 0 . 6 1 4 * *}$ \\
Protein/Total Casein & $\mathbf{0 . 5 9 7 * *}$ \\
Fat/Total Ca & $\mathbf{- 0 . 4 4 1 *}$ \\
Fat/Total P & $\mathbf{0 . 4 1 4 *}$ \\
Lactose/Total citrate & $\mathbf{- 0 . 4 5 2 *}$ \\
Lactose/Total ash & $\mathbf{- 0 . 5 1 1 *}$ \\
Lactose/SCC & $\mathbf{0 . 4 4 4 *}$ \\
Total Ca/Total Mg & $\mathbf{0 . 4 4 6 *}$ \\
Total Ca/Total citrate & $\mathbf{0 . 4 7 6 *}$ \\
Total Ca/SCC & $\mathbf{- 0 . 4 5 7 *}$ \\
Total Mg/Total citrate & $\mathbf{0 . 4 6 4 *}$ \\
Total Mg/Total ash & $\mathbf{- 0 . 4 7 3 *}$ \\
Total P/SCC & $\mathbf{0 . 4 9 2 *}$ \\
Total citrate/Total ash & $\mathbf{0 . 4 3 8 *}$ \\
Total citrate/SCC & $\mathbf{- 0 . 4 9 8 *}$ \\
\hline &
\end{tabular}

Table 4 Correlation coefficients between raw milk compositional parameters over the period from August 2011 to October 2012

Significance levels: $* P<0.05$; $* * P<0.01$; $* * * P<0.001$

568 Total solids=TS; Somatic cell count $=S C C$ 


\begin{tabular}{|c|c|}
\hline Components & Correlation coefficient $(p)$ \\
\hline Density/Lactose & $0.545 * *$ \\
\hline Density/SCC & $0.447 *$ \\
\hline Density/Foaming ability & $0.469 *$ \\
\hline Casein micelle size/pH & $-0.525 * *$ \\
\hline Casein micelle size/TS & $0.410 *$ \\
\hline Casein micelle size/Protein & $-0.494 *$ \\
\hline Casein micelle size/Fat & $0.666 * * *$ \\
\hline Casein micelle size/Total phosphorus & $0.408 *$ \\
\hline Viscosity/pH & $\mathbf{0 . 5 5 5} * *$ \\
\hline Viscosity/Total casein & $0.646 * * *$ \\
\hline Foaming ability/Protein & $0.587 * *$ \\
\hline Foaming ability/Total casein & $0.526 * *$ \\
\hline $\mathrm{RCT} / \mathrm{pH}$ & $0.629 * * *$ \\
\hline $\mathrm{RCT} / \mathrm{Ca}^{2+}$ & $-0.557 * *$ \\
\hline RCT/Protein & $0.678 * * *$ \\
\hline $\mathrm{RCT} / \mathrm{Fat}$ & $-0.470 *$ \\
\hline RCT/Total phosphorus & $-0.653 * * *$ \\
\hline $\mathrm{RCT} /$ Total casein & $0.559 * *$ \\
\hline RCT/Viscosity & $0.421 *$ \\
\hline RCT/Foaming ability & $0.459 *$ \\
\hline $\mathrm{RCT} / \mathrm{ES}$ & $0.639 * * *$ \\
\hline $\mathrm{ES} / \mathrm{pH}$ & $0.757 * * *$ \\
\hline ES/Protein & $0.663 * * *$ \\
\hline $\mathrm{ES} / \mathrm{Fat}$ & $-0.488 *$ \\
\hline ES/Total casein & $0.629 * * *$ \\
\hline ES/Casein micelle size & $-0.436 *$ \\
\hline ES/Viscosity & $0.417 *$ \\
\hline $\mathrm{BC} / \mathrm{SCC}$ & $0.488 *$ \\
\hline
\end{tabular}

Table 5 Correlation coefficients between raw milk compositional parameters and physical properties over the period from August 2011 to October 2012

Significance levels: $* P<0.05$; $* * P<0.01 ; * * * P<0.001$ 
570 Somatic cell count $=S C C ;$ Rennet coagulate time $=R C T ;$ Ethanol stability=ES; Buffering

571 capacity $=B C$

572 


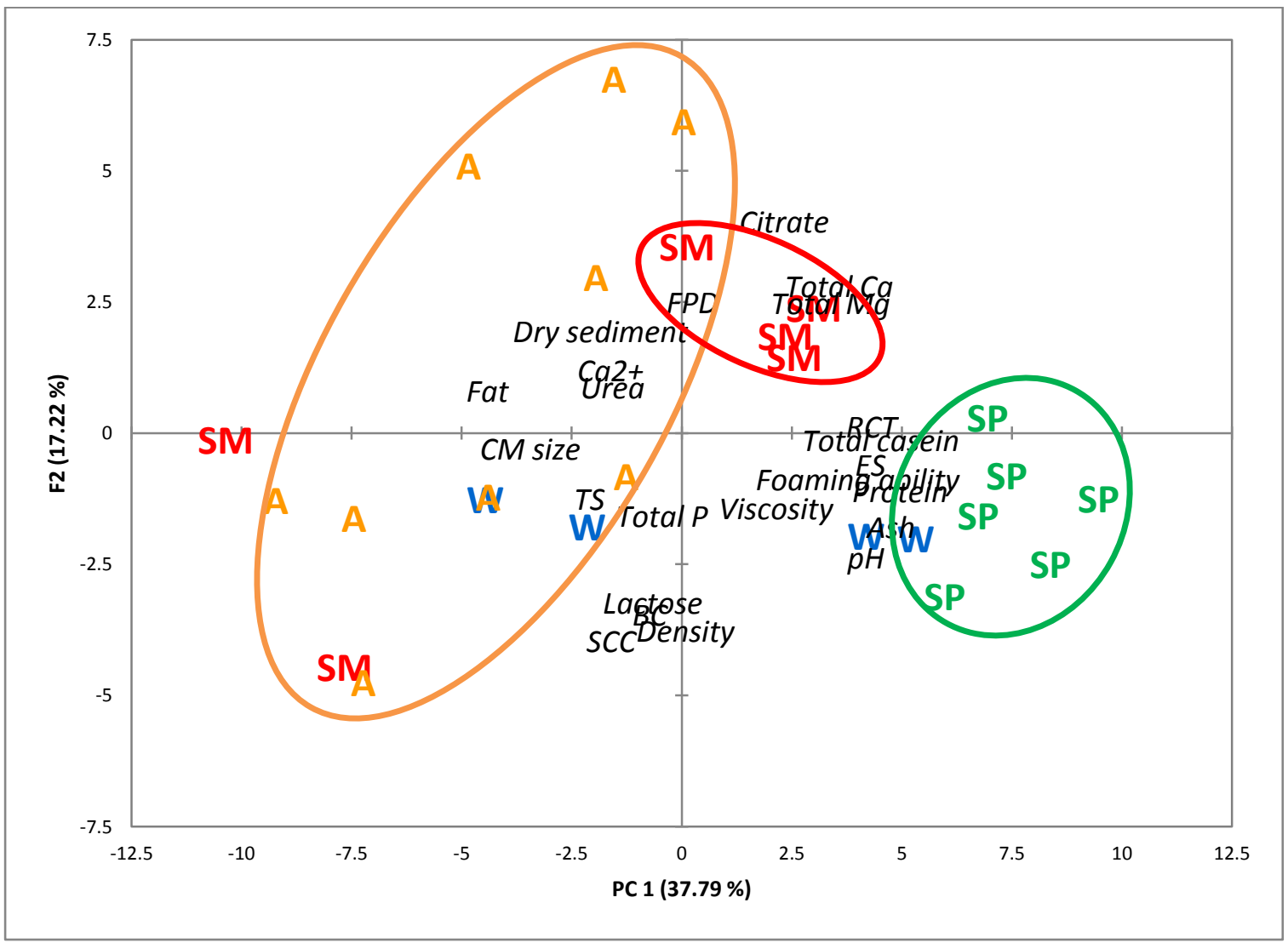

575 Figure 1

$576 \quad$ Figure captions

577 Figure 1. Effect of the seasonal variation on the physico-chemical properties of raw milk

578 according to principal component analysis (PCA) similarity map, determined by

579 principal components PC 1 (37.79 \%) and PC 2 (17.22 \%).

$580 \quad S P=$ Spring; $S M=$ Summer; A=Autumn; $W=$ Winter;

581 Total solids=TS; Buffering capacity= BC; Somatic cell count=SCC; Freezing point depression=FPD;

582 Rennet coagulate time $=R C T ;$ Ethanol stability $=E S ; C M$ size $=$ casein micelle size $; \mathrm{Ca}^{2+}=$ Ionic

583 calcium 